\title{
A REVIEW OF NUTRITION AND PERFORMANCE OF HARD PHYSICAL WORK
}

\author{
J. D. BROOKE DLC, MSc., PhD., and G. J. DAVIES DLC. \\ Preliminary communication - A full article will be published in a later issue.
}

\section{ABSTRACT}

Despite the folk-lore surrounding athletic diets experimental evidence shows that an increase in protein intake is not used for the provision of energy in working muscles. Any extra amount of protein required for the increase in muscle mass is provided in the normal diet. Carbohydrate and fat provide the sources of muscular energy, fat being important at low intensities of work and during work of long duration.

The proportion of carbohydrate used increases with increasing work intensity or with an increase in dietary carbohydrate. Most of the carbohydrate for exercise is supplied by the local glycogen stores in skeletal muscle and with hard physical work over hours these stores are depleted and the subject becomes exhausted. The initial store of muscle glycogen can be altered by changes in diet and with combinations of exercise and diet. These can be summarized as:

1. A carbohydrate rich diet prior to work will greatly increase the duration of work.

2. Feeding carbohydrate during work increases the duration of work.

3. Following exercise to exhaustion a high carbohydrate diet increases the glycogen stores more quickly and to higher levels than other diets.

4. An exercise adaptation can occur. Following successive bouts of work to exhaustion subjects on a normal mixed diet worked longer on their last ride with a greater use of the carbohydrate stores.

\section{KEY REFERENCES}

1. HEDEMAN, R. (1957) Acta Physiol.Scand. 40, 305

2. YAMAJI, R. (1951) J.Physiol.Soc.Japan, 13, 483

3. BERGSTROM and HULTMAN. (1966) Scand.J.Clin. Lab.Invest., 18, 16-20

4. HERMANSEN et al (1967) Acta Physiol. Scand., 71, 129

5. HULTMAN, E. \& BERGSTROM, J. (1967) Acta Med.Scand., 182, 109

6. AHLBORG, B. et al (1967) Forsvarmedicin, 3, 85

7. BROOKE, J. D. and GREEN, L. F. (in press) Proc. Nut.Soc.

8. BROOKE, J. D. and DAVIES, G. J. (1970) Ergonomics, 13, 4, 529

9. BROOKE, J. D., DAVIES, G. J. and GREEN, L. F. (1972) Proc. Nut.Soc., 31, 93

\section{REVIEWS}

1. Nutrition and Athletic Performance. Van Italie et al (1956) J.A.M.A., 1120

2. Diet and Athletic Performance. P. O. Astrand (1967) Federation Proceedings, Vol. 26, No. 6, 1772

3. Dietary Carbohydrate and Work Capacity. Consolazio and Johnson: (1972) Comments in Biochemistry. Am.J.Clin.Nut., 25, 85-90.

4. Food Carbohydrates and Human Performance: in G. G. Birch and L. F. Green (Eds.) Molecular Structure and Function of Food Carbohydrates. London, Elsevier (1973) 